\title{
PREDIKSI LAJU EROSI DAN VALUASI EKONOMI PADA AREA REKLAMASI PERTAMBANGAN BATUBARA
}

\author{
Arief Adi Pradana1, Dr. Ir. Dwi Nowo Martono, M.Si ${ }^{2}$, \\ Dr. Ir. Soemarno Witoro Soelarno, M.Si ${ }^{3}$ \\ ${ }^{1}$ Sekolah Ilmu Lingkungan, Pascasarjana Universitas Indonesia \\ ${ }^{2}$ Sekolah Ilmu Lingkungan, Pascasarjana Universitas Indonesia \\ ${ }^{3}$ Sekolah Ilmu Lingkungan, Pascasarjana Universitas Indonesia \\ Email: arief.ipb@gmail.com
}

\begin{abstract}
Mining activities had positive and negative impacts on the environment. Erosion is one of the negative impacts that must be managed. This research carried out due to the problem of different predicted erosion and the actual condition in one of the reclamation areas of $P T X$. This research aims to analyze the erosion rate and economic value on the mining reclamation activities of $P T X$. This research method carried out using the calculation of erosion rates with USLE, the Erosion Hazard Index $(I B E)$, interviews with village communities around PT X and calculated economic value due to erosion with an economic valuation using Total Economic Value (NET). The results indicate that the calculation of erosion rates with the USLE approach of 35,351.69 tons/ha/year and the value of the Erosion Hazard Index (IBE) with the Very High category dominating reclamation area with a percentage of $61,11 \%$. The results of the economic valuation calculation are $R p 13,7$ billion/year, and the recommended erosion management is to manage factors $C$ and $P$ to reduce the rate of erosion.
\end{abstract}

Keywords: Coal Mine, Reclamation, Erosion, USLE, Economic Valuation 


\section{PENDAHULUAN}

Kegiatan pertambangan adalah sebagian atau seluruh tahapan kegiatan dalam rangka penelitian, pengelolaan dan pengusahaan mineral atau batubara yang meliputi penyelidikan umum, eksplorasi, studi kelayakan, konstruksi, penambangan, pengolahan dan pemurnian, pengangkutan dan penjualan, serta kegiatan pascatambang menurut Undang-Undang No. 4 Tahun 2009 tentang Pertambangan Mineral dan Batubara yang terakhir diubah dengan Undang-Undang No. 3 Tahun 2020 tentang Perubahan Atas Undang-Undang Nomor 4 Tahun 2009 tentang Pertambangan Mineral dan Batubara. Indonesia saat ini menempati peringkat ke-6 dengan sekitar 3,7\% dari total cadangan batubara global, produsen batubara terbesar ke4 di dunia pada tahun 2019 setelah Cina, India dan Amerika (British Petroleum, 2020).

Menurut Environmental Law Alliance Worldwide (2010), kegiatan penambangan selain menimbulkan dampak positif juga dapat menimbulkan dampak negatif terhadap lingkungan hidup terutama dalam hal penurunan kualitas air, perubahan kualitas udara, habitat flora dan fauna menjadi rusak, kualitas kesuburan tanah yang berkurang, berubahnya bentang alam dan konflik sosial. Mempertimbangkan dampak dari kegiatan pertambangan terhadap lingkungan, bekas area tambang harus dilakukan rehabilitasi dengan melakukan reklamasi dan revegetasi (Hazarika et al., 2006). Reklamasi perlu dilakukan untuk mencegah kerusakan lingkungan akibat proses kegiatan penambangan dan tujuan dari kegiatan akhir reklamasi adalah untuk memperbaiki lahan bekas tambang agar dapat tercipta kondisi yang aman, stabil dan tidak mudah tererosi sehingga dapat dimanfaatkan kembali dan mampu memberikan dampak terhadap suatu ekosistem seperti pengaturan keseimbangan karbon dioksida dan oksigen dalam udara, perbaikan sifat-sifat tanah, pengaturan tata air dan sebagainya (Patiung et al., 2011; Yamani, 2012).

Sumber erosi pada kegiatan pertambangan dapat terjadi pada area penambangan aktif/pit yang terletak pada lereng tambang aktif (Choi et al., 2008), area waste dump yang dilakukan reklamasi baik di dalam tambang (reklamasi inpit dump) atau di luar tambang (reklamasi outpit dump) (Patiung et al., 2011; Yamani, 2012; Zulkarnain et al., 2014; Zhang et al., 2015). Situasi ini menyebabkan reklamasi yang gagal disaat tahapan pascatambang. Oleh karena itu, tingkat erosi tanah di area rehabilitasi harus dinilai secara memadai dan 
beberapa tindakan pencegahan harus diambil untuk memantau dan mengelola area rehabilitasi dalam jangka panjang (Inoue et al., 2015).

PT X yang memiliki Izin Usaha Pertambangan (IUP) komoditas batubara di Kabupaten Kapuas, Provinsi Kalimantan Tengah memiliki tingkat produksi maksimum per tahun sebesar 3,9 juta ton dan berada pada kawasan hutan produksi. Pada salah satu area reklamasi PT. X, terjadi erosi alur dan erosi parit sehingga mengakibatkan longsor (Gambar 1) yang berpotensi mempengaruhi lingkungan. Semakin besar potensi erosi yang akan terjadi maka semakin besar juga nilai ekonomi yang dikeluarkan untuk pengendalian, pemeliharaan dan perbaikannya. Penelitian ini bertujuan untuk menganalisis laju erosi tanah yang terjadi di area reklamasi PT $\mathrm{X}$ dan mengetahui nilai ekonomi akibat laju erosi tersebut.

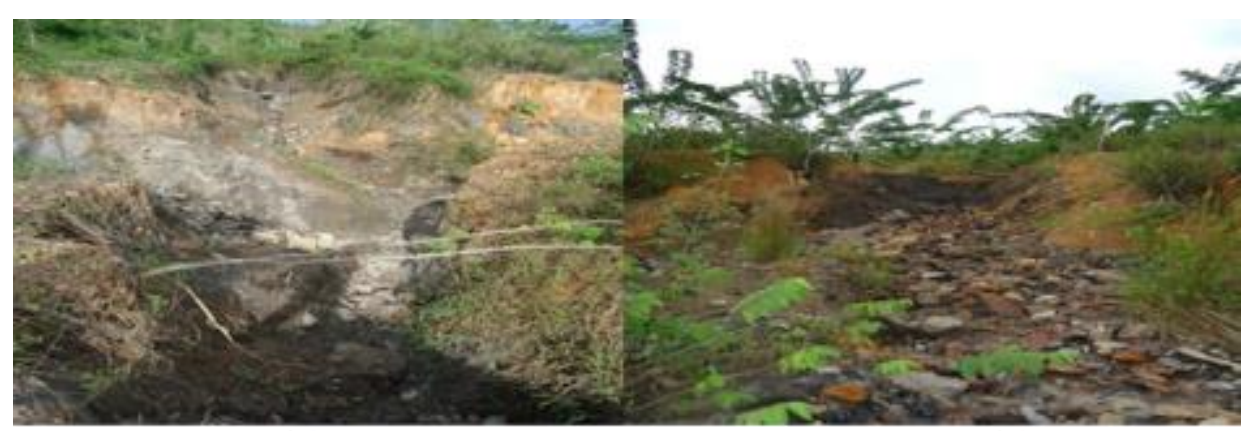

(1)

(2)

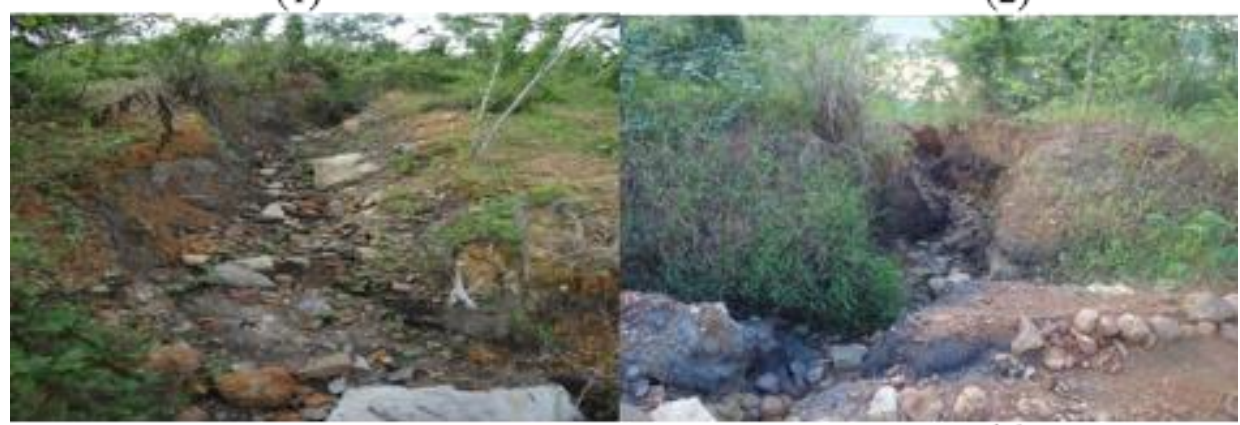

(3)

(4)

Gambar Error! No text of specified style in document.. (1) Longsor (2) Erosi alur (3) Erosi parit (4) Erosi parit pada OPD 2

Sumber: Laporan Reklamasi PT X (2017) dan telah diolah kembali 


\section{METODOLOGI PENELITIAN}

Lokasi penelitian ini berada pada IUP PT X dan desa sekitar PT X yang terkena dampak akibat erosi yang berada di Kabupaten Kapuas, Provinsi Kalimantan Tengah. Penelitian ini menggunakan pendekatan kuantitatif. Riset ini menggunakan mix method yaitu gabungan metode kuantitatif dan kualitatif. Metode kuantitatif yang digunakan adalah perhitungan laju erosi menggunakan USLE (Wischmeier \& Smith, 1978) pada seluruh area reklamasi PT X (8 lokasi) dengan menggunakan perangkat lunak Arc GIS versi 10.7 dimana :

\section{$A=R \times K \times L \times S \times C \times P$}

Keterangan:

A : Banyaknya tanah tererosi dalam ton/ha/tahun;

R : Faktor curah hujan, yaitu jumlah satuan indeks erosi hujan, yang dihitung dengan menggunakan rumus Bols dalam Asdak (2007).

$\mathrm{K} \quad$ : Faktor erodibilitas tanah, yaitu laju erosi per unit indeks erosi untuk suatu tanah yang diperoleh sampel tanah dengan melakukan analisis \%debu, \%pasir sangat halus, \%lempung dan permeabilitas. Nilai K dengan menggunakan rumus Hammer dalam Hardjowigeno, et. al (2007).

LS : Perhitungan panjang lereng (L) dilakukan mulai dari punggung bukit hingga pinggir sungai pada peta topografi. Kemiringan lereng berpengaruh $3 \mathrm{x}$ dari panjang lereng terhadap erosi (Hardjowigeno et al., 2007). Tabel nilai LS sesuai Hammer dalam Hardjowigeno, et. al (2007)

C : Faktor vegetasi penutup tanah dan pengelolaan tanaman, yaitu nisbah antara besarnya erosi dari suatu areal dengan vegetasi penutup dan pengelolaan tanaman tertentu terhadap besarnya erosi dari tanah yang identik tanpa tanaman.Tabel Penilaian Faktor P sesuai Hammer dalam Hardjowigeno, et. al (2007).

P : Faktor tindakan konservasi tanah, yaitu nisbah antara besarnya erosi dari tanah yang diberi perlakuan tindakan konservasi tanah seperti pengelolaan menurut kontur, penanaman dalam strip atau teras terhadap besarnya erosi dari tanah yang diolah searah lereng dalam keadaan yang identik. Tabel Penilaian Faktor P sesuai Arsyad (2012).

Setelah mendapatkan nilai laju erosi (A), kemudian menghitung nilai Indeks Bahaya Erosi (IBE) dengan melakukan perhitungan nilai erosi yang dapat diperbolehkan (Edp). 
Tabel 1. Klasifikasi IBE

\begin{tabular}{|c|c|}
\hline Indeks Bahaya Erosi & Kategori \\
\hline$<1,00$ & Rendah \\
\hline $1,01-4,00$ & Sedang \\
\hline $4,01-10,00$ & Tinggi \\
\hline$>10,00$ & Sangat Tinggi \\
\hline
\end{tabular}

Sumber: Wood et al. dalam Hardjowigeno et al. (2007)

Metode perhitungan nilai ekonomi dengan valuasi ekonomi dengan pendekatan ekonomi, lingkungan dan sosial (Suparmoko, et al., 2007; Indah, 2011). Metode kualitatif pada riset ini adalah pengumpulan data melalui pengisian kuisioner oleh penduduk desa sekitar IUP PT X yang terkena dampak dari erosi dengan jumlah 50 orang dari populasi 100 orang yang tinggal di sempadan sungai di desa sekitar PT. X.

\section{HASIL DAN PEMBAHASAN}

Hasil penelitian ini menunjukkan nilai $\mathrm{R}$ adalah 687,16 , hasil ini lebih rendah dari Haryo Saputro (2019) terkait erosi di Provinsi Kalimantan Tengah yang memiliki nilai R dengan rentang 1.195 - 1.542. Hal ini dikarenakan perbedaan luas wilayah penelitian, penggunaan beberapa data stasiun curah hujan dan perbedaan metode perhitungan erosivitas hujan namun sudah mendekati dan AMDAL PT X (2014) dengan nilai R sebesar 555,9. Faktor curah hujan memiliki nilai yang cukup signifikan lebih tinggi dibandingkan dengan penelitian terkait dengan penilaian potensi erosi di area tambang pada Provinsi Kalimantan Selatan oleh Anggraini et al. (2019) dengan nilai R sebesar 399,7 dan Yamani (2012) dengan nilai R sebesar 334,27. Nilai erodibilitas tanah (K) pada seluruh area berkisar antara 0,25 - 0,72 (sedang - sangat tinggi). Hal ini akan mengakibatkan meningkatnya laju erosi sesuai dengan penelitian Sarminah et al. (2017) dimana tanah yang erodibilitasnya tinggi akan rentan terkena erosi, dibandingkan tanah yang erodibilitasnya rendah.

Kemiringan lereng yang paling dominan pada area reklamasi adalah 15 - 25\% dengan nilai LS sebesar 3,10. Sebagian besar area reklamasi memiliki nilai kemiringan lereng 0 - 8\%, 8 - 15\% dan 15 - 25\% dengan jumlah persentase sebesar $84,62 \%$ dan nilai ini sudah sesuai dengan rencana desain area reklamasi sesuai dengan standar geoteknik yang ditetapkan dalam dokumen Studi Kelayakan PT X dengan kemiringan lereng maksimal $20^{\circ}$ atau $36 \%$. 
Nilai faktor $\mathrm{C}$ didapat berdasarkan kondisi aktual di lapangan dan penentuan luas area berdasarkan pengamatan dengan drone. Nilai $\mathrm{C}$ sebesar 0,1 dianggap penutupan lahan sudah baik dimana penutupan vegetasi sudah rapat. Nilai $\mathrm{C}$ sebesar 0,5 dianggap penutupan lahan masih belum rapat, LCC belum tumbuh secara merata, sedangkan untuk nilai $\mathrm{C}$ sebesar 1 adalah area reklamasi yang tutupan tajuknya belum tumbuh sama sekali atau memang LCC tidak tumbuh.

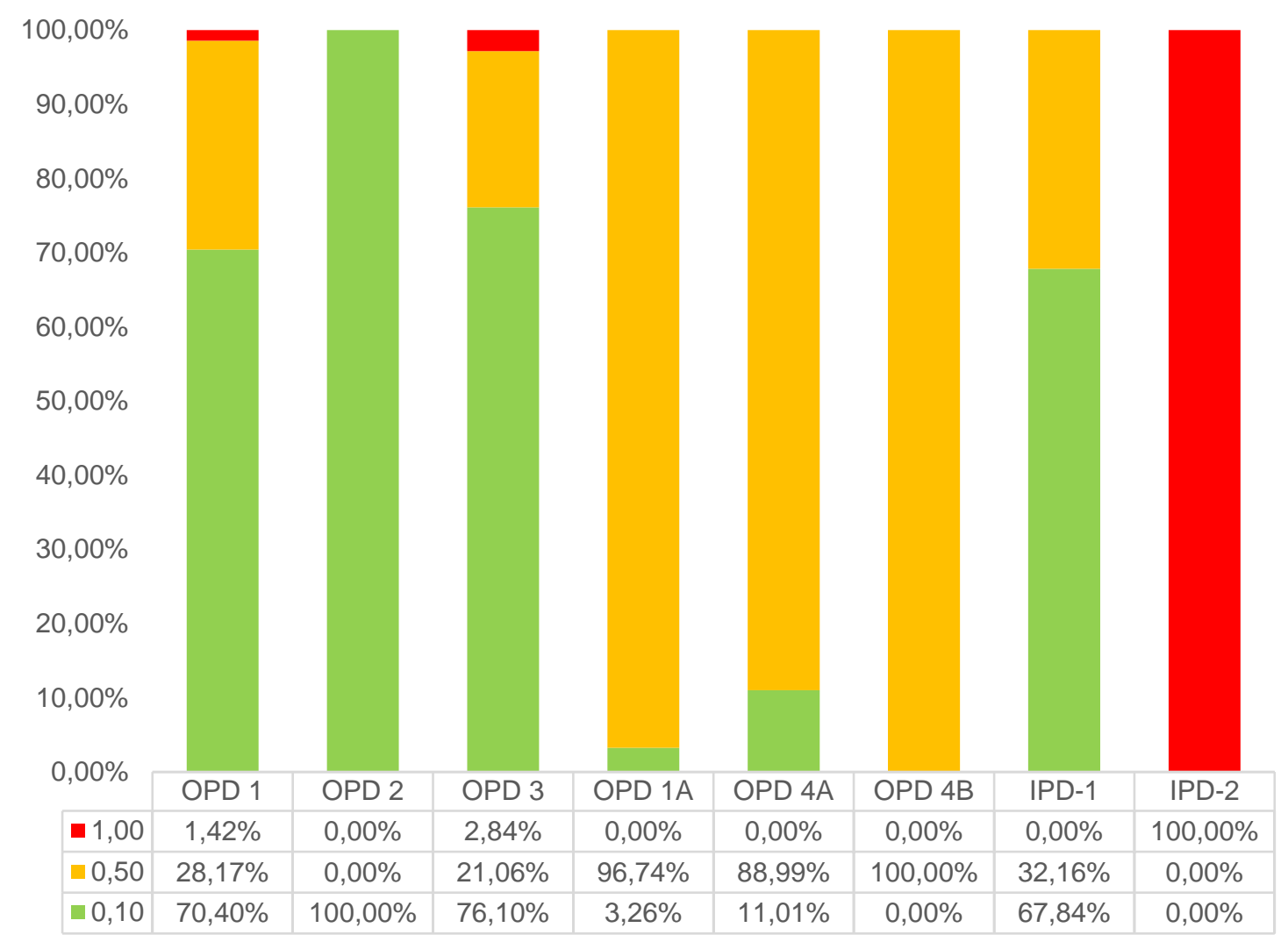

Gambar 2. Persentase Nilai C Setiap Area Reklamasi

Pada Gambar 2, nilai C sebesar 0,1 atau tutupan lahan sudah rapat terlihat pada area reklamasi tahun 2011-2016 atau area reklamasi yang sudah berumur 5-9 tahun yang memiliki tutupan lahan yang sudah baik. Area reklamasi tahun 2016-2018 seperti OPD 1A, 4A, 4B memiliki nilai C sebesar 0,5 yang dominan. Hal ini terjadi karena Legum Covercrops (LCC) yang ditanam tidak tumbuh juga dan pertumbuhan tajuk tanaman juga kurang baik. IPD-2 memiliki persentase nilai C sebesar 1 yang tertinggi karena baru ditanam di akhir tahun 2019 dan belum terlihat adanya pertumbuhan LCC. 

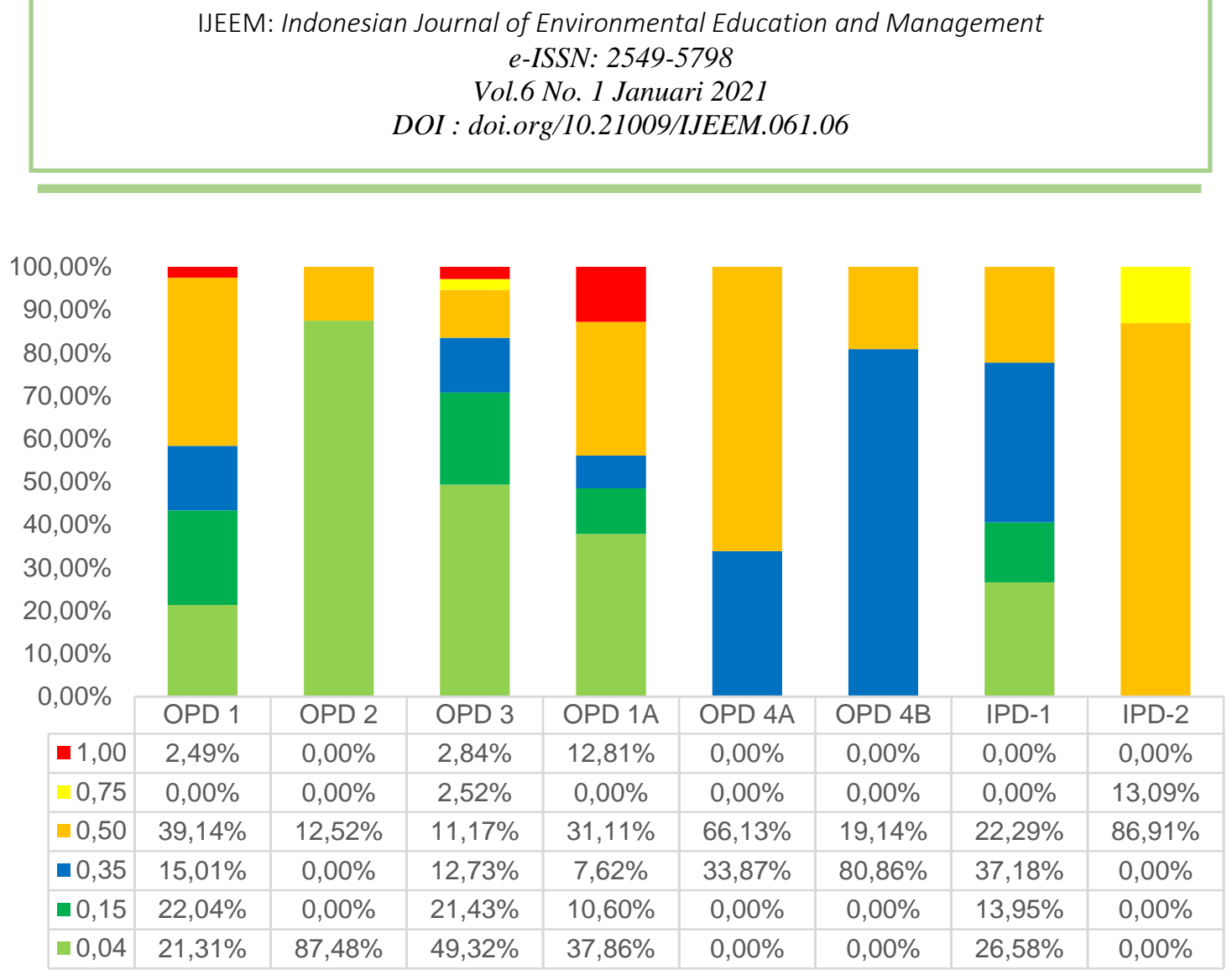

Gambar 3. Persentase Nilai P pada Setiap Area Reklamasi

Nilai faktor P didapat berdasarkan kondisi aktual di lapangan dan penentuan luas area berdasarkan pengamatan dengan drone. Pada Gambar 3, didapatkan nilai faktor P dengan nilai 0,04 atau teras bangku kondisi sempurna dengan persentase luas area reklamasi sebesar $37,82 \%$, nilai 0,15 teras bangku kondisi sedang sebesar $11,08 \%$, nilai 0,35 atau teras bangku kondisi jelek sebesar 17,36\%, nilai 0,5 atau contour cropping dengan kemiringan 0-8\% sebesar 29,75\%, nilai 0,75 atau contour cropping dengan kemiringan 9-20\% sebesar 1,75\% dan nilai 1 atau tanpa tindakan konservasi sebesar 2,23\%. Persentase nilai P sebesar 0,04 tertinggi di OPD 2 dibanding area lain dan pada beberapa area seperti OPD 1, OPD 3 dan OPD 1A terdapat area yang tidak memiliki tindakan konservasi tanah (Nilai $\mathrm{P}=1$ ). Hal ini juga terlihat pada area OPD 3 yang mengalami longsor sebanyak tiga titik dan pada area OPD 1 dan OPD 1A tidak terlihat adanya longsor. Secara keseluruhan, area reklamasi PT. X sudah dilakukan tindakan konservasi namun terlihat sebesar 37,82\% didominasi oleh teras bangku dengan kondisi sempurna karena bentuk area reklamasi dibuat dengan berjenjang dan menggunakan teras bangku. Pada Gambar 4, dapat dilihat salah satu bangunan pengendali erosi di OPD yaitu drop structure yang dibuat dari ban bekas, kayu dan batu gamping. 

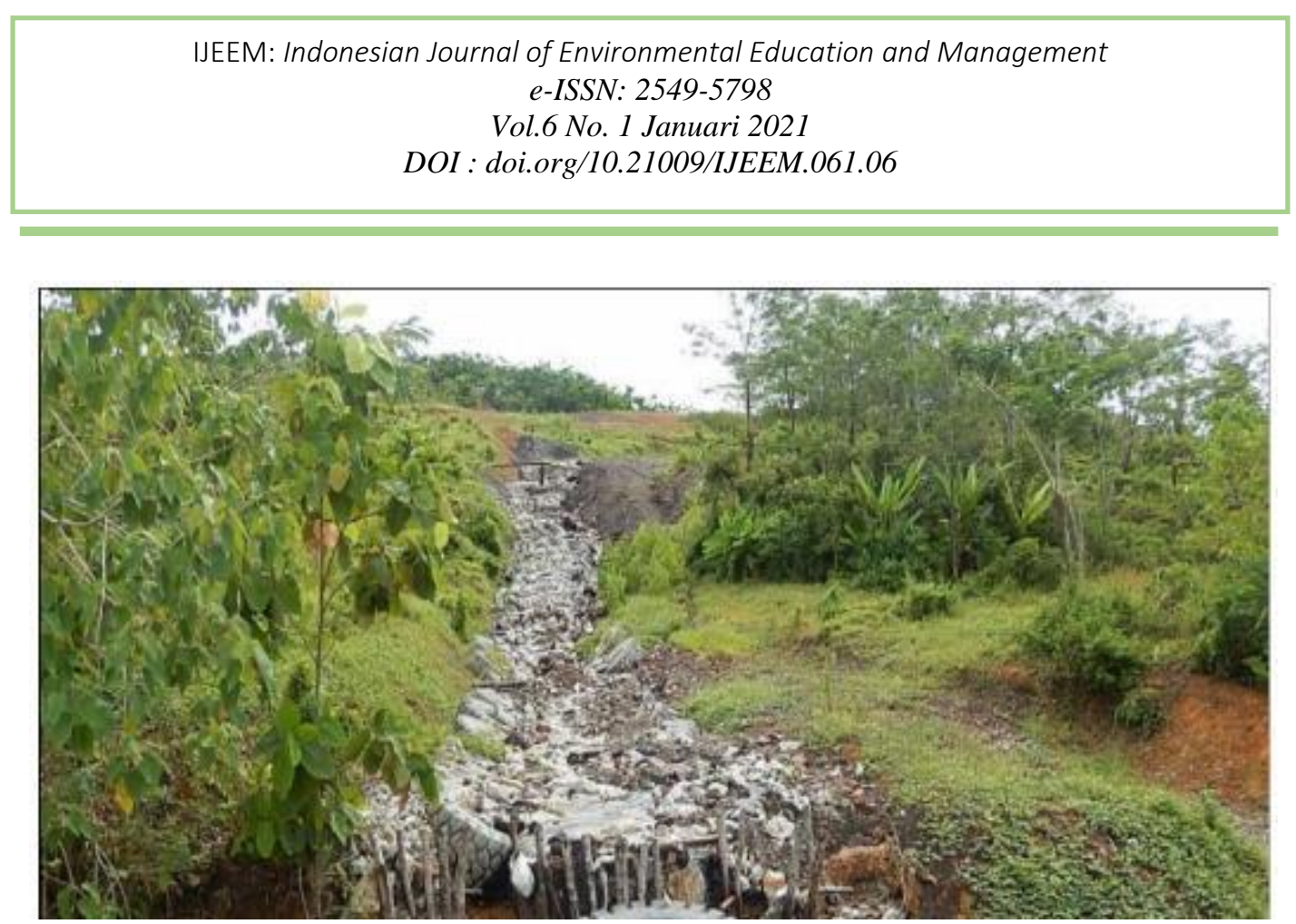

Gambar 4. Drop structure di OPD 2

Analisis jumlah tingkat bahaya erosi dilakukan pada area reklamasi PT X. Area reklamasi ini terbagi menjadi menjadi delapan lokasi. Untuk perhitungan erosi dilakukan dengan menggunakan USLE dan dilakukan analisis spasial dengan menggunakan data drone dan perangkat lunak ArcGIS versi 10.7. Berdasarkan besaran nilai faktor R, K, LS, C dan P pada setiap satuan lahan dianalisis spasial menggunakan perangkat lunak ArcGIS versi 10.7 dengan menggunakan fitur overlay, didapatkan poligon dengan jumlah 54. Setelah itu dengan pendekatan rumus USLE dalam penentuan laju erosi. 
Tabel 2. Nilai Laju Erosi (A) Pada Area Reklamasi

\begin{tabular}{|c|c|c|c|c|c|c|c|c|}
\hline \multirow{2}{*}{ Lokasi } & \multirow{2}{*}{$\begin{array}{l}\text { Luas } \\
\text { (Ha) }\end{array}$} & \multicolumn{5}{|c|}{ Faktor Pembentuk Erosi } & $\mathbf{A}$ & A/Luas \\
\hline & & $\mathbf{R}$ & $\mathbf{K}$ & $\mathbf{L S}$ & C & $\mathbf{P}$ & \multicolumn{2}{|c|}{ Ton/Ha/Tahun } \\
\hline OPD 1 & 53,1 & \multirow{8}{*}{687,16} & 0,34 & 2,53 & 0,37 & 0,46 & 9731,5 & 183,25 \\
\hline OPD 2 & 51,97 & & 0,33 & 2,93 & 0,1 & 0,16 & 71,24 & 1,37 \\
\hline OPD 3 & 64,2 & & 0,29 & 2,73 & 0,43 & 0,46 & 8204,58 & 127,8 \\
\hline OPD 1A & 20,96 & & 0,25 & 3,73 & 0,45 & 0,55 & 5299,55 & 252,89 \\
\hline OPD 4A & 16,05 & & 0,34 & 2,93 & 0,42 & 0,41 & 1700,75 & 105,98 \\
\hline OPD 4B & 23,27 & & 0,72 & 2,53 & 0,5 & 0,39 & 1584,61 & 68,1 \\
\hline IPD-1 & 8,99 & & 0,25 & 2,42 & 0,23 & 0,32 & 771,57 & 85,82 \\
\hline IPD-2 & 22,6 & & 0,29 & 2,93 & 1 & 0,69 & 7987,89 & 353,47 \\
\hline & & & & & $\mathrm{Ju}$ & ah & $35.351,69$ & $1.178,67$ \\
\hline
\end{tabular}

Pada Tabel 2 dapat dilihat bahwa jumlah nilai laju erosi (A) sebesar 35.351,7 Ton/Ha/Tahun. OPD 3 memiliki jumlah laju erosi terbesar dibanding area lain sebesar 8.204,57 Ton/Ha/Tahun, OPD 2 memiliki jumlah laju erosi paling kecil sebesar 71,23 Ton/Ha/Tahun dan rata-rata paling kecil sebesar 1,37 Ton/Ha/Tahun dan IPD-2 memiliki ratarata laju erosi terbesar dibandingkan area lain sebesar 353,47 Ton/Ha/Tahun.

Berdasarkan perhitungan nilai Erosi yang diperbolehkan (Edp) dari masing-masing lokasi reklamasi, didapatkan hasil bahwa nilai Edp berkisar dari 6,3 Ton/Ha/Tahun - 9,54 Ton/Ha/Tahun. Terjadi perbedaan nilai Edp, karena perbedaan bobot isi tanah dari masingmasing lokasi reklamasi, selain itu faktor kedalaman efektif tanah, kedalaman tanah, kedalaman minimum tanah, faktor kelestarian tanah, laju pembentukan tanah adalah sama untuk semua lokasi. Untuk mendapatkan Indeks Bahaya Erosi (IBE) dilakukan pembagian antara nilai A pada setiap masing-masing area dengan Edp. 


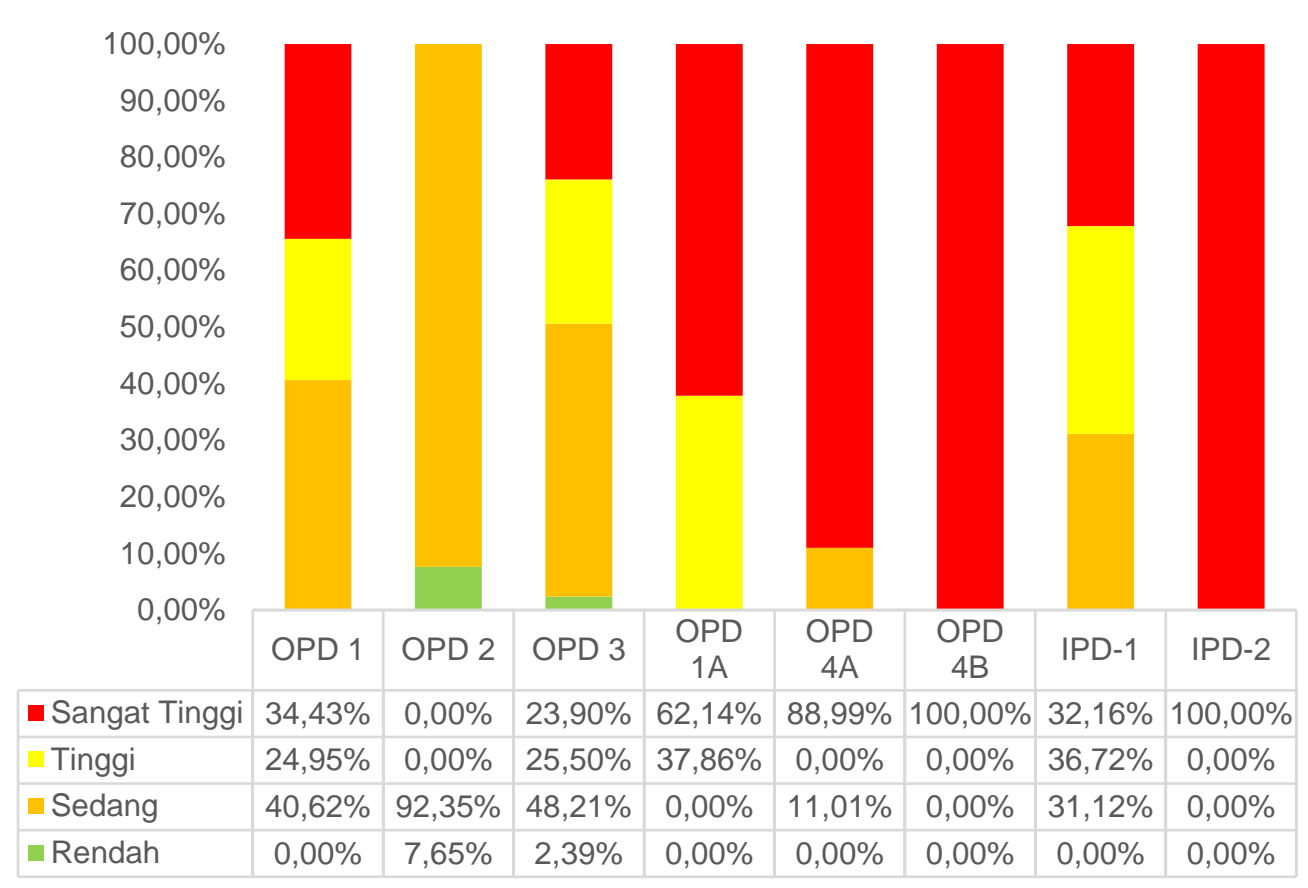

Gambar 5. Persentase IBE Setiap Area Reklamasi

Pada Gambar 5, nilai IBE tidak terlihat perbedaan signifikan pada area OPD 1, OPD 1A, OPD 2 dan OPD 3. Perbedaan signifikan terlihat pada OPD 4A, OPD 4B dan IPD-2 yang memiliki IBE sangat tinggi diatas 50\%, hal ini karena OPD 4A dan OPD 4B memiliki nilai faktor $\mathrm{K}$ yaitu agak tinggi, nilai $\mathrm{C}$ yang tinggi dengan rata-rata sebesar 0,55 dan 0,56 serta $\mathrm{P}$ sebesar 0,35 yang mendominasi dengan persentasi lebih besar dari 80\%. Area IPD-1 memiliki proporsi IBE tinggi dan sangat tinggi cukup berimbang. IPD-2 memiliki persentase IBE sangat tinggi yang dominan meskipun memiliki nilai faktor $\mathrm{K}$ yaitu sedang namun banyak memiliki proporsi yang tinggi untuk nilai $\mathrm{C}$ dan $\mathrm{P}$ yang mendekati

Hasil ini sama dengan penelitian Yamani (2012), dimana area reklamasi umur 5 tahun masih memiliki IBE Tinggi dan tidak sesuai dengan Patiung et al. (2011) dimana umur area reklamasi 6 tahun memiliki laju erosi 8,26 ton/ha dan umur 15 tahun memiliki laju erosi 7,64 Ton/Ha/Tahun dan jika diasumsikan memiliki Edp yang sama dengan penelitian ini maka predikat IBE keduanya adalah rendah. Nilai Indeks Bahaya Erosi (IBE) dengan kategori Sangat Tinggi mendominasi area reklamasi dengan persentase $61,11 \%$, hal ini karena area tersebut belum optimal dalam meningkatkan faktor vegetasi $(\mathrm{C})$ dan faktor konservasi tanah (P) seperti pemantauan pembentukan lereng area reklamasi dengan Robotic Total Station 
(RTS) sehingga bisa terbentuk sesuai standar, penanaman LCC dengan metode hydroseeding atau dengan jenis desmodium sp. Gambar 6. menunjukkan zonasi IBE setiap kategori.

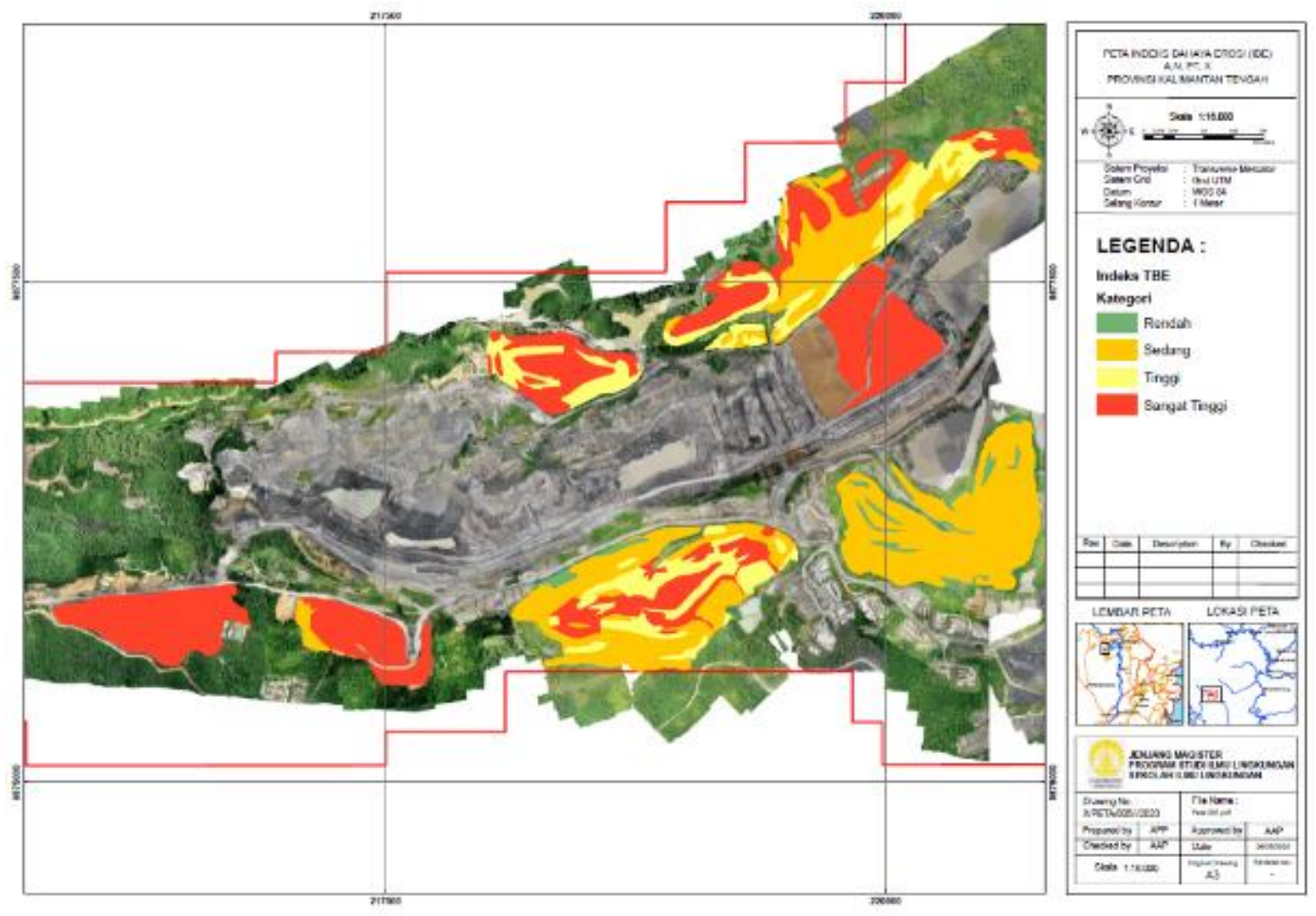

Gambar 6. Peta IBE Area Reklamasi

Hasil perhitungan valuasi ekonomi pada Tabel 3 adalah Rp13.710.900.495 per tahun. Nilai total valuasi ekonomi ini lebih kecil dibandingkan riset Suparmoko et al. (2007), namun jika dilihat dari perbandingan antara total valuasi ekonomi dengan laju erosi dengan pada penelitian tersebut adalah Rp45.841 (Total valuasi ekonomi adalah Rp42.190.853.932 dan volume erosi 920.371 ton/ha) sedangkan pada riset ini adalah Rp387.843. 
Tabel 3. Valuasi Ekonomi Akibat Erosi Di Area Reklamasi

\begin{tabular}{|c|c|c|c|c|}
\hline No & Sub-Variabel & Dampak & Indeks & $\begin{array}{c}\text { Nilai } \\
\text { (Rp/Tahun) }\end{array}$ \\
\hline 1 & $\begin{array}{l}\text { Penurunan fungsi area reklamasi dalam } \\
\text { membentuk unsur hara tanah }\end{array}$ & Onsite & $\mathrm{BL}_{1}$ & 3.614.686.818 \\
\hline 2 & $\begin{array}{l}\text { Kehilangan fungsi area reklamasi dalam } \\
\text { Penatagunaan lahan }\end{array}$ & Onsite & $\mathrm{BL}_{2}$ & 55.174 .656 \\
\hline 3 & $\begin{array}{l}\text { Kehilangan fungsi area reklamasi dalam } \\
\text { Penebaran tanah zona pengakaran }\end{array}$ & Onsite & $\mathrm{BL}_{3}$ & 280.176 .260 \\
\hline 4 & $\begin{array}{l}\text { Kehilangan fungsi area reklamasi dalam } \\
\text { pengendalian erosi dan sedimentasi }\end{array}$ & Onsite & $\mathrm{BL}_{4}$ & 740.210 .937 \\
\hline 5 & $\begin{array}{l}\text { Kehilangan fungsi area reklamasi dalam } \\
\text { revegetasi }\end{array}$ & Onsite & BL5 & 270.504 .159 \\
\hline 6 & Penurunan kualitas air sungai & Offsite & BL6 & 3.901 .232 .000 \\
\hline 7 & Nilai hasil hutan (Kayu) & Onsite & $\mathrm{BE}_{1}$ & 915.867 .012 \\
\hline 8 & Nilai PNBP IPPKH area reklamasi & Onsite & $\mathrm{BE}_{2}$ & 3.105 .444 .929 \\
\hline 9 & Penurunan hasil hutan akibat erosi/longsor & Offsite & $\mathrm{BE}_{3}$ & 55.651 .509 \\
\hline 10 & $\begin{array}{l}\text { Peningkatan pendapatan dari penciptaan lapangan } \\
\text { kerja akibat dari adanya kegiatan reklamasi }\end{array}$ & Offsite & $\mathrm{BE}_{4}$ & 739.996 .312 \\
\hline 11 & Penurunan kualitas kesehatan masyarakat & Offsite & $\mathrm{BS}_{1}$ & 31.955 .904 \\
\hline \multicolumn{4}{|c|}{ Pendekatan lingkungan } & 8.861 .984 .829 \\
\hline & \multicolumn{3}{|c|}{ Pendekatan Ekonomi } & 4.816 .959 .762 \\
\hline & \multicolumn{3}{|c|}{ Pendekatan Sosial } & 31.955 .904 \\
\hline & \multicolumn{3}{|c|}{ Total Valuasi Ekonomi } & 13.710 .900 .495 \\
\hline \multicolumn{4}{|c|}{ Total biaya } & 12.055.037.171 \\
\hline \multicolumn{4}{|c|}{ Total manfaat } & 1.655 .863 .324 \\
\hline
\end{tabular}

\section{KESIMPULAN}

Area reklamasi PT X sebagian besar memiliki IBE dengan kategori Sangat Tinggi dan Nilai ekonomi akibat erosi dihitung dengan valuasi ekonomi dengan menggunakan pendekatan Nilai Ekonomi Total (NET) berdasarkan pendekatan lingkungan, ekonomi dan sosial adalah Rp13,7 milyar/tahun. Penanganan erosi yang disarankan adalah mengelola faktor $\mathrm{C}$ dan $\mathrm{P}$ supaya bisa mengurangi laju erosi. 


\section{REFERENSI}

Anggraini, L. R., Agus, A. T., Novianti, Y. S., Mulyono, E. E., \& Yuliyanto, Y. (2019). Indeks Bahaya Erosi Pada Lahan Reklamasi. Jurnal GEOSAPTA, 5(2), 141.

Asdak, C.(2007). Hidrologi dan Pengelolaan Daerah Aliran Sungai, Gadjah Mada University Press, Yogyakarta.

Arsyad, S.(2006). Konservasi Tanah dan Air. Serial Pustaka IPB Press. Bogor.

Badan Pusat Statistik Provinsi Kalimantan Tengah.(2015). Jumlah Kasus Pencemaran Lingkungan Hidup Provinsi Kalimantan Tengah Tahun 2014. www.kalteng.bps.go.id. Diakses pada 18 September 2018, pukul 22.10 WIB.

British Petroleum. (2020). BP Statistical Review of World Energy 2020. https://www.bp.com/content/dam/bp/businesssites/en/global/corporate/pdfs/energy-economics/statistical-review/bp-statsreview-2020-full-report.pdf. Diakses pada 29 Juni 2020, pukul 22.10 WIB.

Choi, Y., Park, H. D., \& Sunwoo, C. (2008). Flood and Gully Erosion Problems At The Pasir Open Pit Coal Mine, Indonesia: A Case Study Of The Hydrology Using GIS. Bulletin of Engineering Geology and the Environment, 67(2), 251-258.

Environmental Law Alliance Worldwide. (2010). Guidebook For Evaluating Mining Project Eias. Environmental Law Alliance Worldwide Journal.

Hammer, W.I. (1978). Soil Conservation Report INS/78/006. Technical Note No. 7. Soil Research Institute, Bogor.

Hardjowigeno, S; Widiatmaka. (2007). Evaluasi Kesesuaian Lahan \& Perencanaan Tata Guna Lahan. Cetakan Pertama. Gajah Mada University Pres. Yogyakarta.

Haryo Saputro, R.(2019). Study of Erosion and Sedimentation Potentials In The Watershed Of The Kahaya River In Central Kalimantan Province. Jurnal Teknologi Berkelanjutan, Vol. 8, No.2:69-76

Hazarika P, Talukdar NC, Singh YP. (2006). Natural Colonization oOf Plant Species on Coal Mine Spoils At Tikak Colliery, Assam. International Soc Trop Ecol 47 (1): 37-46.

Indah Ria, S. (2011). Valuasi Ekonomi Kawasan Berpotensi Erosi. Program Studi Ilmu Lingkungan, Program Pascasarjana. Universitas Indonesia.

Inoue, N., Hamanaka, A., Shimada, H., Sasaoka, T., \& Matsui, K. (2015). Fundamental Study on Assessment of Soil Erosion By The USLE Method At Rehabilitation Area In Indonesian Coal Mine. Earth Science Research, 4(1), 61-67. 
Patiung, O., Sinukaban, N., Tarigan, S. D., \& Darusman, D. (2011). Pengaruh Umur Reklamasi Lahan Bekas Tambang Batubara Terhadap Fungsi Hidrologis. Jurnal Hidrolitan, 2(2), 60-73.

PT. X. (2014). Dokumen AMDAL. Kalimantan Tengah.

PT. X. (2019). Laporan Realisasi Reklamasi Tahun 2018, Kalimantan Tengah.

Sarminah, S., Kristianto, D., \& Syafrudin, M. (2017). Analisis Tingkat Bahaya Erosi Pada Kawasan Reklamasi Tambang Batubara PT Jembayan Muarabara Kalimantan Timur. Hutan Tropis, 1(2), 154-162.

Suparmoko, Sudirman D., Setyarko, Y., Wibowo, H.S. (2007). Valuasi Ekonomi Sumberdaya Alam dan Lingkungan. BPFE: Yogyakarta.

Wischmeier, W. H; Smith, D.D. (1978). Predicting Rainfall Erosion Losses: A Guide to Conservation Planning. Science and Education Administration. United States Department of Agriculture in Cooperation with Purdue Agriculture Experiment Station. Washington, D.C.

Yamani, A. (2012). Studi besarnya erosi pada areal reklamasi tambang batubara di PT Arutmin Indonesia Kabupaten Kotabaru. Jurnal Hutan Tropis, 13(1), 46-54.

Zhang, L., Wang, J., Bai, Z., \& Lv, C. (2015). Effects of vegetation on runoff and soil erosion on reclaimed land in an opencast coal-mine dump in a loess area. Catena, 128, 4453. https://doi.org/10.1016/j.catena.2015.01.016

Zulkarnain, Joy, B., Tuhpawana, P., \& Prawira, I. (2014). Soil Erosion Assessment of The Post-Coal Mining Site in Kutai Kartanagera District, East Kalimantan Province. International Journal of Science and Engineering, 7(2), 130-136. 